\section{Ólafur Helgi Samúelsson}

lyf- og öldrunarlæknir flæðisvið̌i Landspítala

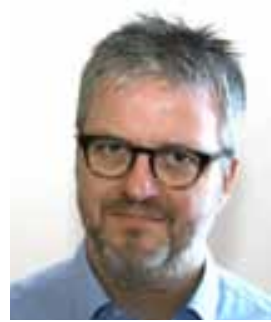

Í pessu tölublaði Læknablaðsins er birt ágæt rannsókn Kristófers A. Magnússonar og félaga á afdrifum sjúklinga, 60 ára og eldri, sem gengust undir skurðaðgerð eftir mjaðmarbrot á Landspítala árið 2011. Athugaðar voru afturskyggnt eftirfarandi breytur: Biðtími eftir aðgerð, tegund brota og aðgerðar og afdrif sjúklinga. Athygli vekur hversu hátt dánarhlutfall í hópnum var ári eftir aðgerð, eða 27\%. Petta er áttfalt hærra en meðaltal dánartíðni einstaklinga yfir 60 ára aldri á Íslandi og í efri mörkum miðað við erlendar rannsóknir. Marktækt færri gátu búið á eigin heimili eftir brot en fyrir. Aldur sjúklinga, biðtími eftir aðgerð, áhættustigun samkvæmt ASA-flokkun og pað hvort sjúklingur var á hjúkrunarheimili fyrir brot, reyndust spápættir fyrir dauða eftir 12 mánuði. Athyglisvert er að aðeins $37 \%$ gátu útskrifast heim í beinu framhaldi af spítalalegunni og er pað lægra hlutfall en í tilvitnuðum erlendum rannsóknum. ${ }^{1}$ Niðurstöður rannsóknarinnar ríma annars vel við erlendar rannsóknir og undirstrika pað hversu viðkvæman hóp hér er um að ræða. Í rannsókninni var ekki gerð frekari greining á ástæðum dauða eða færniskerðingar en pað gæti verið verðugt rannsóknarefni á pessum hópi sjúklinga, sem telur að jafnaði um 200-300 manns árlega á Landspítala.

Aldraðir eru engan veginn einsleitur hópur með tilliti til heilsufars en fjölgun hinna elstu veldur pví óhjákvæmilega að fleiri einstaklingar glíma við fjölvanda og hrumleika. Mjaðmarbrot er heilsufarsáfall sem nær eingöngu tilheyrir eldri aldurshópunum og frekar konum en körlum. Áætlað er að árlega mjaðmarbrotni um

\title{
Lifið heil!
}

20 af hverjum 10.000 körlum og um 60 af hverjum 10.000 konum eldri en 55 ára. Meðalaldur pessara sjúklinga er yfir 80 ár og flestir brotna við lágorkuáverka.

Stór hluti eldri mjaðmarbrotssjúklinga eru hrumir með marga samverkandi sjúkdóma og margir verða fyrir varanlegri færniskerðingu í kjölfar brots. Mjaðmarbrot eru iðulega meiriháttar áfall, bæði fyrir sjúklinga og fjölskyldur peirra. Meðal alvarlegra afleiðinga má telja dauðsföll, óráð, punglyndi, verki, hræðslu við að detta, félagslega einangrun, margpætta færniskerðingu og auknar líkur á pví að purfa að flytjast á stofnun. Horfur, bæði til skemmri og lengri tíma, eru slæmar. Dánartíðni 12 mánuðum eftir brot í pessum hópi er 18-30\% samkvæmt rannsóknum. Reikna má með að um 40\% sjúklinga nái ekki fyrri hreyfifærni og um fimmtungur er kominn á stofnun ári eftir brot. ${ }^{2,3}$

Skurðaðgerð sem fyrst eftir brot er algjör forsenda pess að möguleiki sé á bata en styðja má pað rökum að mjaðmarbrot sé ekki síður öldrunarsjúkdómur en viðfangsefni bæklunarlækna. Heildræn öldrunarlæknisfræðileg nálgun og teymisvinna er valkostur við hefðbundna sjúkrahúsmeðferð pessara sjúklinga fyrir og eftir aðgerð og víða eru reknar deildir í samstarfi bæklunarlækna og öldrunarlækna með petta í huga. Á Norðurlöndunum eru starfræktar slíkar „orthogeriatriskar“ deildir par sem sýnt hefur verið fram á betri árangur en við hefðbundna starfsemi allt að ári eftir aðgerð, meðal annars varðandi hreyfigetu, vitræna getu og lífsgæði. Kostnaðargreining bendir einnig til lægri heildarkostnaðar en við hefðbundna nálgun. ${ }^{4}$ Erfiðlega hefur gengið að sýna fram á lægri dánartíðni sem enn undirstrikar hversu viðkvæmur pessi hópur er og margir sjúklinga nærri lokum lífs.

Forvarnir til að draga úr nýgengi mjaðmarbrota eru lýðheilsuverkefni og mikilvægt er að stuðla að góðri beinheilsu alla ævi með hollu mataræði, hreyfingu, nægu D-vítamíni, reykleysi og, sérstaklega á efri árum, byltuvörnum og viðeigandi beinpéttnimeðferð. Reglubundin hreyfing, næring, heilsufarseftirlit og regluleg endurskoðun lyfjalista með ástand og horfur einstaklingsins í huga eru mikilvægir pættir byltuvarna hjá öldruðum.

Núlifandi kynslóðir mannkyns njóta peirrar blessunar að líkur á að ná háum aldri eru meiri en nokkru sinni í sögunni. Íslendingar búa við einhverjar lengstu lífslíkur sem pekkjast í heiminum. Við erum enn ung miðað við nágrannapjóðir okkar og 65 ára og eldri eru tæplega 13\% pjóðarinnar um pessar mundir. Pessi hlutföll breytast pó hratt. Samkvæmt spám Hagstofu Íslands gætu 65 ára og eldri Íslendingar orðið nær 100.000 talsins og tæpur fjórðungur pjóðarinnar árið 2050.

Tækifæri til að nýta betur mannauð, reynslu og sköpunarkraft eldri kynslóða blasa við og mikilvægt er að samfélög búi sig undir pessar breytingar. Рað er einnig áskorun að aðlaga heilbrigðispjónustu að pörfum fjölveikra og hrumra einstaklinga pannig að sómi sé að og afdrif sjúklinga með mjaðmarbrot geta verið einn mælikvarði á hvernig til tekst. Fyrir áhugasama um stefnumótun samfélaga til framtíðar mætti benda á nýútkomna skýrslu Alpjóðaheilbrigðisstofnunarinnar WHO: Ageing and Health (who.int/ageing/publications/ world-report-2015/en/). Lifið heil!

\section{Heimildir}

1. Magnússon KA. Meðferð og afdrif sjúklinga með mjaðmarbrot. Læknablaðið 2016; 102: 119-24.

2. Bentler SE, Liu L, Obrizan M, Cook EA, Wright KB, Geweke JF, et al. The aftermath of hip fracture: discharge placement, functional status change, and mortality. Am J Epidemiol 2009; 170: 1290-9.

3. Nikitovic M, Wodchis WP, Krahn MD, Cadarette SM. Direct health-care costs attributed to hip fractures among seniors: a matched cohort study. Osteoporos Int 2013; 24: 659-69

4. Prestmo A, Hagen G, Sletvold O, Helbostad JL, Thingstad $\mathrm{P}$, Taraldsen $\mathrm{K}$, et al.,Comprehensive geriatric care for patients with hip fracture: a prospective, randomised controlled trial. Lancet 2015; 385: 1623-33.
On hip fracture and ageing

Ólafur Helgi Samúelsson MD, Specialist in Internal Medicine and Geriatrics, Landspitali University Hospital Iceland 